\title{
Reward Manajemen untuk Membentuk Psychology Well-being dalam Mengurangi Terjadinya Demo
}

\author{
Muhammad Alif Yudha ${ }^{1}$, Soffy Balgies ${ }^{2}$, Yunia Lailatul Mafuz ${ }^{3 *}$, Triningtyas ${ }^{4}$ \\ 1,2,3,4 Departemen Psikologi, Fakultas Psikologi Dan Kesehatan \\ Universitas Islam Negeri Sunan Ampel, \\ Surabaya60237, Indonesia
}

j91219130@student.uinsby.ac.id; soffybalgies@uinsby.ac.id; j91219134@student.uinsby.ac.id;

j91219113@student.uinsby.ac.id

*Correspondence: j91219134@student.uinsby.ac.id

\begin{abstract}
The purpose of this journal research is to find how to provide salary system and THR to employees at PT Crevis Tex Jaya Subang West Java and analyze the impact and solution. With the method of reviewing case studies at PT Crevis Tex Jaya Subang West Java caused by the late payment of salaries to employees of PT Crevis Tex Jaya even THR still delinquent and make the employees down action or demo to demand their rights. Salary giving and THR have applicable invitations.
\end{abstract}

Keywords: Pay; Human Resources; Psychology Well Being.

\begin{abstract}
ABSTRAK
Tujuan dilakukan penelitian jurnal ini adalah untuk mengetahui bagaimana pemberian system gaji dan THR pada karyawan di PT Crevis Tex Jaya Subang Jawa Barat serta penganalisisan dampak dan penyelesaiannya. Dengan metode peninjauan studi kasus di PT Crevis Tex Jaya Subang Jawa Barat yang di sebabkan oleh telatnya pembayaran gaji pada karyawan PT Crevis Tex Jaya bahkan THR masih tetap menunggak dan membuat para karyawan turun aksi atau demo untuk menuntut hak nya. Pemberian gaji dan THR mempunyai prundangundangan yang berlaku.
\end{abstract}

Kata Kunci: Gaji; Sumber Daya Manusia; Kesejahteraan Psikologi.

\section{PENDAHULUAN}

Bagian investasi utama pada organisasi atau perusahaan ialah sumber daya manusia (SDM). Oleh karena itu, beberapa perusahaan fokus dalam mengembangkan sumber daya manusianya. Ketika seseorang menjual sebuah perusahaan, seseorang tersebutakan melihat nilai sumber daya manusianya, artinya jika kualitas sumber daya manusianya baik maka nilai beli perusahaan tersebut bisa lebih tinggi dari total aset dan pembiayaan fisik. Sumber daya manusia (SDM) yang berkualitas ialah sumber daya dengan kemampuan dan keterampilan tinggi yang memungkinkan berkembangnya perusahaan terkait. Jika perusahaan tidak dapat menjalankan tugasnya secara normal tanpa sumber daya manusia, maka perusahaan tidak akan beroperasi secara normal. Oleh karena itu, sumber daya manusia memegang peranan penting dalam setiap area bisnis perusahaan.

Tingkat kemampuan kerja juga termasuk dalam faktor untuk menentukan kuantitas dan kualitas barang serta jasa yang di produksi oleh perusahaan. Semakin banyak jumlah tenaga kerja yang terdidik dan terampil, maka kualitas terbaik pada produksi barang dan jasa juga semakin tinggi.Bisa dikatakan, tenaga kerja termasuk 
dalam aset perusahaan, untuk mencapai sebuah tujuan perusahaan. Namun, bila tenaga kerja yang terdidik dan terampil hanya sedikit, maka perusahaan tersebut akan mengalami keterlambatan dalam usaha mencapai tujuan perusahaaan.

Pada dasarnya, perusahaan diwajibkan untuk memberi dan memenuhi hak tiap karyawan yang bekerja untuk perusahaan tersebut. Contohnya ialah jaminan perlindungan dalam keselamatan kerja, jaminan kesehatan terutama gaji dan THR untuk karyawan, begitu juga mengenai kewajiban yang diterapkan oleh perusahaan kepada karyawannya. Tanpa gaji yang diberikan oleh perusahaan berakibat karyawan akan kesulitan dalam memenuhi kebutuhan sehari-harinya karena tidak mendapat pemasukan dari apa yang telah mereka kerjakan di perusahaan tersebut.

Gaji adalah imbalan/balasan yang diberikan kepada perusahaan terkait tugas-tugas yang telah dijalankan oleh para karyawan sesuai dengan tingkatan dan jenis pekerjaannya.Gaji ini meliputi tunjangan yang digunakan pada waktu yang relatif cukup panjang, seperti sebulan atau setahun.Gaji juga merupakan motivasi yang penting agar karyawan dapat lebih mendorong semangat karyawan untuk giat dalam bekerja dan melakukan hasil yang baik.Motivasi dan semangat para karyawan harus di tingkatkan agar melaksakan kinerja yang baik. Namun sebaliknya, apabila karyawan tidak memiliki motivasi yang tinggi dalam bekerja, maka hasil yang diperoleh tidak akan maksimal, sehingga individu bias sulit bekerja dengan baik dan kurang bertanggung jawab dalam melakukan pekerjaannya sekalipun individu tersebut mempunyai kemampuan operasional yang baik (Panudju, 2003).

Untuk memotivasi karyawan agar dapat meningkatkan kinerja tentu juga di support atau di dukung dengan pemberian kompensasi yaitu berupa gaji atau upah yang sepadan atas timbal balik hasil pencapaian yang dilakukan oleh para karyawan, ini terbukti dengan terdapatnya tren kenaikan biaya gaji yang dikeluarkan perusahaan selain dari faktor Inflasi dan juga peraturan pemerintah. Dari besarnya kenaikan gaji ini tentu para manajer berharap dapat meningkatkan kinerja karyawan yang nantinya akan berpengaruh kepada produktivitas kerja perusahaan.

Menurut Hasibuan (2010) motivasi kerja ialah hal yang sulit karena perusahaan tidak mengetahui apa keinginan dan kebutuhan karyawan. Ia juga berpendapat bahwa motivasi kerja adalah proses internal dan eksternal bagi setiap individu, sehingga menimbulkan antusiasme dan konsistensi dalam melakukan suatu kegiatan. Karena itu, karyawan akan merasa nyaman dan termotivasi untuk bekerja dan melakukan suatu kegiatan yang ada dalam perusahaan. Sehingga kesejahteraan psikologis manusia dapat terpenuhi karena kenyamanan yang tercipta.

Kesejahteraan psikologi (psychological well being) yang berarti sentosa, sejahtera dan makmur. Menurut Kementrian Koordinator Kesejahteraan Rakyat, 'sejahtera'memiliki arti bahwa kondisi masyarakat telah memenuhi kebutuhan dasarnya. Kebutuhan tersebut meliputi mutu pangan, kesehatan, sandang, papan, pendidikan, dan lapangan pekerjaan serta lingkungan yang aman dan nyaman untuk ditinggali.Serta terpenuhinya kebutuhan hak asasi manusia dan terwujudnya masyarakat/warga yang bertakwa kepada Tuhan yang Maha Esa.Terganggunya kesejahteraan psikologi dapat terpengaruhi oleh keadaan ekonomi.

Kesejahteraan ini tidak hanya digambarkan tentang kondisi pada mental seseorang, melainkan bagaimana individu dapat menyadari adanya sumber daya psikologis pada dirinya dan dapat mengaplikasikannya. (Christopher, 1999; Huppert, 1999; Moeenizadeh \& Sala-game, 2010).

Dalam kondisi penyebaran Covid-19, ekonomi perumahan sebagian telah menurun karena orang lebih sering berada di dalam negeri untuk melakukan aktivitas luar ruangan.Apalagi dengan adanya perusahaan PT Crevis Tex Jaya yang memiliki komitmen untuk membayar tarif dan tunjangan kesempatan bagi para pekerjanya. Bagaimanapun, perusahaan menyatakan alasan kepada deden bahwa mereka tidak memiliki uang tunai, sehingga perusahaan membayar para pekerja kompensasi 50 persen dan sisa kompensasi dibayarkan pada akhir bulan. Untuk THR, perusahaan memberi 20 persen pada 20 Mei dan sisanya dibayarkan bertahap pada Oktober, yang sudah dikomunikasikan dengan Kepala Dinas Tenaga Kerja dan Transmigrasi Subang, THR saat itu belum jelas.

Tugas moral fundamental yang muncul dari sudut pandang 'rasional' organisasi / industri berpusat pada dua komitmen etis, yaitu a) komitmen dari yang lazim untuk mematuhi perintah atasan dalam organisasi / industri dalam mewujudkan tujuan organisasi / industri, dan b ) Kewajiban masyarakat umum untuk memberi gaji yang wajar dan dengan kondisi kerja yang baik. Berdasarkan keajaiban yang terjadi di atas, alasan pembuatan artikel diary ini adalah untuk mengetahui bagaimana kondisi perusahaan dalam memberikan tarif gaji kepada para pekerjanya di tengah maraknya Covid-19 yang mewabah di seluruh dunia. Indonesia. Dalam perluasannya, artikel diary ini dibuat untuk menganalisis kondisi kesejahteraan mental pekerja dalam menerima upah yang sebagian diberikan. 


\section{METODE PENELITIAN}

Secara spesifik, perusahaan memiliki beberapa komitmen, salah satunya ialah bahwa perusahaan wajib menawarkan kompensasi yang mencerminkan dominasi bahaya dalam pameran kerja yang komparatif namun kompetitif.Selain itu wajib memberikan kompensasi kepada perwakilan sebagai akibat dari kerja keras pekerjaan mereka.

\section{Gaji}

Dalam kamus umum, gaji dicirikan sebagai angsuran terjadwal yang diselesaikan, lebih sering daripada tidak dibayarkan dari bulan ke bulan.tetapi secara teratur dikomunikasikan sebagai jumlah tahunan, yang dibuat oleh manajer kepada seorang pekerja, terutama seorang profesional. Gaji bisa menjadi kerangka angsuran dari seorang manajer kepada seorang pekerja yang dapat diputuskan dalam kontrak kerja.Dibedakan menjadi gaji satuan, di mana setiap pekerjaan, jam, atau unit lainnya dibayar secara mandiri, tidak terputus-putus.Dari sudut pandang menjalankan perdagangan, gaji juga dapat dilihat sebagai pengorbanan untuk mendapatkan dan mempertahankan aset manusia untuk menjalankan perusahaan, dan kemudian disebut biaya.Dalam pembukuan, tingkat gaji dicatat dalam akun keuangan.

Menurut As'ad (1995: 93), gaji disebut juga upah, tetapi perbedaannya adalah gaji ialah jumlah uang yang didapat dan ditetapkan, serta waktu yang selalu tepat. Seperti, setiap awal bulan pekerja akan Penerimaan sejumlah uang, yang bisa disebut gaji, dan upah adalah uang yang diterima tidak selalu sama atau tidak pasti, dan waktunya sudah ditentukan sebelumnya. Oleh karena itu, perbedaan upah dan gaji menjadi jaminan atas ketepatan waktu dan kepastian uang yang mereka terima.

Karyawan di setiap perusahaan memiliki tempat tinggal yang berbeda, dan menggeser jumlah kompensasi yang diberikan. Pekerja yang telah bekerja lebih dari 1 tahun lebih sering diklasifikasikan sebagai perwakilan lama, sedangkan pekerja tidak terpakai yang telah bekerja untuk waktu yang lama 0-1 diklasifikasikan sebagai pekerja tidak terpakai.Adanya klasifikasi ini membuat kontras dengan jumlah kompensasi.Penghitungan gaji atau upah bisa menjadi gerakan rutin setiap bulan.Semua komponen dikumpulkan dan setelah itu dihitung dengan sangat hati-hati.Perusahaan berupaya mengatur upah pekerja secara sah, memenuhi hak-hak pekerja secara layak, dengan tetap menjaga harga diri perusahaan dalam etalase kerja. Jika kerangka keuangan perusahaan buruk, itu pasti akan mengurangi minat ahli potensial untuk menghubungkan perusahaan. Kerangka kompensasi untuk karyawan yang tidak terpakai lebih sering didasarkan pada tingkat instruksi dan posisi tanpa mempertimbangkan variabel lain seperti keterlibatan kerja, keterampilan dan jumlah tanggungan.

Faktor kompensasi diukur dengan penanda.Penanda ini dibagi menjadi dua, khususnya ekuitas dalam dan ekuitas luar. Ekuitas dalam bisa berupa angsuran yang terkait dengan harga kerja relatif sehingga spesialis mendapatkan gaji yang sama. Ekuitas luar seperti membayar pekerja sebanyak apa yang didapat spesialis pada tingkat yang sama dengan perusahaan lain. Bersamaan dengan (Mas'ud, 2004: 357) Ekuitas dalam dan luar diisolasi menjadi beberapa bagian, seperti yang terjadi berikut:

1. Keadilan dalam internal

a. Keadilan dalam internal pada kenaikan gaji

b. Keadilan dalam internal pada tunjangan

c. Keadilan dalam internal pada insentif

d. Keadilan dalam internal pada gaji

2. Keadilan dalam eksternal
a. Keadilan dalam eksternal pada kenaikan gaji
b. Keadilan dalam eksternal pada tunjangan
c. Keadilan dalam eksternal pada insentif
d. Keadilan dalam eksternal pada gaji

Faktor-faktor yang mempengaruhi besar kecilnya Upah/gaji yang diterima karyawan menurut tokoh Panjojo dan Suad (2005), yaitu sebagai berikut:
a. Penawaran dan permintaan pada tenaga kerja
b. Organisasi para buruh
c. Kemampuan untuk membayar pekerja
d. Produktivitas dalam berkerja
e. Biaya hidup pekerja
f. Pemerintah 
Berikut ini langkah-langkah dalam menentukan besar kecilnya upah/ Gaji, yaitu:

a. Analisis pada Jabatan

Analisis pada jabatan ialah suatu kegiatan yang dilakukan untuk mencari informasi mengenai tugas yang dilakukan oleh karyawan, serta syarat-syarat yang diperlukan untuk melaksanakan tugas agar berhasil merumuskan uraian tugas, spesifikasi pekerjaan, dan standar kerja.Hal ini diperlukanuntuk mengevakuasi karyawan.

\section{b. Evaluasi pada Jabatan}

Evaluasi pada jabatan merupakan proses yang sistematis guna menentukan nilai relatif suatu pekerjaan dibanding pekerjaan lain. Evaluasi jabatan biasanya dilaksanakan dengan membandingkan isi atau faktor pekerjaan, Misalnya tanggung jawab, tingkat usaha atau kemampuan, keterampilan ketika bekerja, kesulitan pekerjaan dan lingkungan kerja.

\section{c. Survei pada Gaji}

Survei pada gaji adalah kegiatan yang bertujuan untuk menemukan tingkat gaji yang diterima secara adil dari perusahaan mana pun dengan posisi serupa.Hal ini dilakukan agar keadilan eksternal menjadi faktor yang penting dalam perencanaan dan penetapan besaran gaji karyawan.

\section{d. Penentuan pada Gaji}

Penentuan pada gaji biasanya menggunakan suatu metode dimana besaran gaji akan ditentukan sesuai dengan metode yang digunakan oleh perusahaan.

\section{Tunjangan Hari Raya (THR)}

Tunjangan Hari Raya (THR) ialah pendapatan non-upah yang diberikan kepada semua karyawan yang telah bekerja selama satu bulan sebelum hari raya keagamaan Islam. Tunjangan hari raya ialah objek pajak penghasilan (PPh 21) yang menjadi tanggung jawab wajib pajak perorangan.Pemotongan pajak penghasilan THR21 berbeda untuk setiap karyawan.Selain tergantung besar kecilnya objek pajak, pengurangan pajak penghasilan juga dipengaruhi oleh kepemilikan Nomor Pokok Wajib Pajak (NPWP). Karyawan yang tidak memiliki NPWP akan mendapatkan potongan harga sebesar 20\% dibandingkan dengan karyawan yang telah memiliki NPWP. Beberapa orang menggunakan THR untuk membeli kebutuhan sehari-hari dan membeli baju baru.Sebagian orang masih mengandalkan THR dan sangat mengharapkan uang dari THR karena uangnya lumayan.

\section{Psychology Well Being}

Menurut Ryff (1995), kesejahteraan pada psikologis merupakan pencapaian penuh yang berasal dari potensi dalam psikologis individu dan keadaan saat dimana individu bisa menerima kelemahan maupun kekuatan yang ada pada dirinya. Selain itu, individu memiliki tujuan dalam hidup, membangun relasi yang baik dengan orang lain, menjadi individu yang mandiri, dapat mengontrol lingkungan sekitar, dan berkembang secara mandiri.

Aspek - aspek Ryff menjelaskan enam aspek dalam psychology well being. Yaitu:

a. Penerimaan pada diri

Nilai positif penerimaan pada diri, ialah dapat menerima dan mengakui aspek diri, baik itu dari kualitas diri yang baik ataupun yang buruk, dan merasa positif terhadap kehidupan yang ada di masa lalu. Sedangkan nilai negatif dalam penerimaan diri adalah tidak pernah merasa puas dengan diri, ingin menjadi berbeda dari dirinya yang saat ini, merasa bersalah dengan kualitas diri, serta merasa dikecewakan oleh apa yang terjadi di masa lalu.

\section{b. Relasi positif dengan orang lain}

Memiliki hubungan yang terpercaya dengan orang lain, memiliki empati, intimasi dan afeksi yang kuat, merasa peduli terhadap kesejahteraan orang lain, tserta memberi dan menerima dalam hubungan antar manusia. Sedangkan relasi negatif dalam aspek ini adalah sulit untuk hangat dan terbuka kepada orang lain.

\section{c. Otonomi}

Dalam otonomi yang baik, seseorang dapat mengambil keputusan sendiri, mengatur dan mengevaluasi diri dengan standar personal. Namun sebaliknya, jika dalam otonomi yang kurang baik, seseorang akan bergantung pada penilaian orang lain untuk membuat sebuah keputusan penting, serta mengkonfirmasi tekanan social untuk bertindak dan berpikir dengan cara tertentu. 


\section{d. Penguasaan lingkungan}

Dalam aspek penguasaan lingkungan yang baik, individu dapat membuat atau memilih konteks yang sesuai dengan kebutuhan dan nilai personalnya.Sedangkan dalam penguasaan lingkungan yang buruk, seseorang kurang mengontrol dunia luar sehingga tidak mampu mengubah dan meningkatkan konteks yang ada disekelilingnya.

\section{e. Tujuan dalam hidup}

Seseorang memiliki tujuan dan objektivitas dalam hidup, sedangkan jika seseorang tidak memiliki tujuan hidup mereka akan kurang dalam memahami makna kehidupan dan tidak memiliki pandangan atau keyakinan dalam kehidupan.

f. Pertumbuhan personal

Seseorang melihat dirinya tumbuh dan berkembang serta terbuka dalam pengalaman yang baru, juga memiliki cara yang dapat merubah dan merefleksikan pengetahuan dalam diri dan efektivitas yang lebih banyak. Namun, jika individu memiliki partumbuhan personal yang kurang, maka mereka akan bosan dan tidak tertarik pada kehidupan serta merasa tidak mampu dalam mengembangkan sikap atau perilaku.

\section{HASIL DAN PEMBAHASAN}

Sumber daya manusia sangat penting dalam peningkatan organisasi atau perusahaan. Tanpa sumber daya manusia, organisasi tidak dapat berjalan dengan lancar. Menyetujui pernyataan Lyons et al (1993) dan Flecther dan Williams (1996) memberi pernyataan bahwa komitmen organisasi perwakilan untuk melanjutkan bekerja sebagai bagian dari organisasi / perusahaan dapat meningkat jika didukung oleh munculnya inspirasi tinggi dari pekerja yang terkait dengan pekerjaan di mana mereka bekerja. Manajemen sumber daya manusia mencakup semua bentuk pilihan manajemen yang secara langsung mempengaruhi sumber daya manusianya.MSDM menyangkut rencana dan pelaksanaan kerangka kerja pengaturan, penataan pekerja, kemajuan pekerja, manajemen karir, penilaian kerja, pemberian kompensasi dan hubungan kerja yang hebat.

Begitupun juga dengan karyawan di perusahaan PT. Crevis Tex Jaya di Subang, karyawan berdemo untuk menuntut turunnya gaji yang seharusnya diberikan kepada para karyawannya.Apabila perusahaan memanajemen karyawan tersebut dengan baik, maka motivasi karyawan untuk bekerja juga meningkat.Namun, dengan tidak adanya penurunan gaji, karyawan PT Crevis Tex Jaya, membuat karyawan melakukan aksi turun ke jalan untuk menuntut turunnya gaji mereka.Deden menyatakan bahwa pimpinan perusahaan tidak memiliki itikad baik dalam sejumlah perundingan terkait pembayaran gaji dan THR. Selain itu, ia juga mengungkapkan bahwa erusahaan berdalih tidak memiliki uang, padahal proses impor, ekspor, hingga produksi pun masih tetap berjalan.

Jae (2000) menunjukkan bahwa agar dapat memajukan organisasi dan kinerja pegawai, diperlukan inspirasi pegawai yang sangat layak di tiru. Faktor motivasi ini dapat diukur melalui faktor intrinsik seperti kebutuhan akan pencapaian dan kepentingan. Adapun factor luar yang terdiri dari promosi, keamanan kerja, dan gaji.Semakin teraturnya perusahaan dalam memberikan gaji dan tunjangan pada karyawannya, semakin meningkat pula motivasi kerja dari karyawan tersebut.Signifikansi sumber daya manusia dalam sebuah organisasi mengharuskan setiap organisasi untuk menginduksi perwakilan yang berkualitas dan menguntungkan untuk menjalankan organisasi. Maka dari itu, perlu adanya kedisiplinan pada setiap organisasi agar karyawan juga disiplin dalam melaksanakan tugasnya dengan baik.

Menyetujui pernyataan Notoatmodjo, tujuan pendekatan pemberian emolument/kompensasi incorporate: Apresiasi pencapaian pekerja, Menjamin kewajaran tarif gaji pekerja, Menjaga pekerja atau penurunan omzet pekerja, Mendapatkan pekerja yang berkualitas, Mengambil kendali tol, kontrol Majelis. Dapat dikatakan bahwa pemberian remunerasi/kompensasi ini selain sebagai bingkai apresiasi perusahaan atas karyawannya ketergantungan dalam bekerja. Hal ini apalagi dapat memungkinkan lebih banyak dukungan kepada karyawan dalam mencapai target yang diberikan oleh perusahaan untuk jangka panjang.

Setiap orang memerlukan uang untuk membiayai kehidupan sehari-harinya oleh karena itu mereka berkerja keras untuk mendapatkan uang.Uang yang didapat dari berkerja disebut upah/gaji. Namun jika perusahaaan/ tempat kerja tidak membayar gaji, maka masyarakat tidak akan dapat memenuhi kebutuhan hidupnya. Psikologi well-being karyawan akan terganggu jika kebutuhan hidupnya tidak terpenuhi. Apabila kesejahteraan karyawan 
terganggu maka kualitas kerja mereka menurun. Bahkan dapat membuat perusahaan merugi karena bisa saja kayawan memilih keluar untuk mendapatkan perkerjaan yang lebih baik. Sangat disayangkan perusahaan tidak membayar gaji dengan tepat. Ketentuan dalam pembayaran upah/gaji sudah diatur dalam peraturan pemerintah (PP) pada bagian pengupahan No 78 Tahun 2015 pada bait Ketiga. Pada hari atau tanggal pembayaran, gaji harus diberikan berdasarkan perjanjian antara perusahaan dan karyawan, misalnya disepakati secara lisan, tertulis selama perjanjian kerja/penandatanganan kontrak kerja, atau dinyatakan dalam peraturan perusahaan tersebut.

Dalam Pasal 18 menyebutkan sebagai berikut:

Perusahaan wajib untuk memberi upah/gaji pada waktu yang sudah diperjanjikan antara perusahaan dan pekerja. Pada hari atau tanggal yang sudah disepakati oleh kedua belah pihak jatuh pada hari libur atau hari yang diliburkan, atau hari istirahat mingguan, pelaksanaan pembayaran upah/gaji diatur dalam perjanjian kerja/kontrak kerja, peraturan perusahaan.

Pasal 19 dan 20 juga menjelaskan sebagai berikut :

Pemberian upah/gaji oleh perusahaan wajib dilakukan dalam jangka waktu paling cepat seminggu satu kali atau selambat-lambatnya sebulan satu kali. kecuali jika pada perjanjian/kontrak kerja untuk waktu kurang dari satu minggu. Upah/gaji harus dibayarkan seluruhnya pada setiap periode dan setiap tanggal pembayaran upah/ gaji.

Pada Pasal 21 dan 22 juga mengatur, bahwa upah/gaji wajib dibayarkan dalam bentuk mata uang rupiah, serta dibayarkan secara langsung ataupun lewat bank. Dalam hal dibayarkan melalui bank, upah/gaji harus dapat diuangkan pada tanggal pembayaran upah yang telah disepakati.

Jika perusahaan telat memberikan upah/gaji, maka perusahaan akan mendapatkan sanksi. Keterlambatan pembayaran gaji/upah berakibat perusahaan dikenai denda sesuai dengan ketentuan dalam Pasal 55, sebagai berikut:

1. Perusahaan sebagaimana dengan yang sudah tertulis dalam Pasal 53 apabila terlambat membayar dan/atau tidak membayar upah/gaji sebagaimana yang dimaksud pada Pasal 5 ayat (4) maka akan dikenai denda dengan ketentuan:

a. Dimulai dari hari keempat hingga hari kedelapan terhitung pada tanggal yang seharusnya upah/gaji dibayar, dikenakan denda sebesar 5\% (lima persen) untuk setiap hari pada keterlambatan dari hari upah/ gaji yang seharusnya dibayarkan;

b. Apabila sesudah hari kedelapan, upah/gaji belum terbayarkan, maka akan dikenai denda sebagaimana dengan yang dimaksud huruf (a) yaitu ditambah $1 \%$ (satu persen) untuk setiap hari keterlambatan dengan ketentuan 1 (satu) bulan tidak boleh melebihi 50\% (lima puluh persen) dari upah yang seharusnya dibayarkan; dan

c. Jika sesudah sebulan, upah masih belum dibayar juga, maka akan dikenai denda keterlambatan sebagaimana dengan yang dimaksud dalam huruf (a) dan huruf (b) yaitu ditambah bunga sebesar suku bunga yang berlaku pada bank pemerintah.

2. Pengenaan denda sebagaimana dengan yang dimaksud pada ayat (1) tidak menghilangkan kewajiban pengusaha untuk tetap membayar upah kepada pekerja/buruh.

Dengan demikian, Peraturan Pemerintah (PP) Pengupahan memberikan toleransi pembayaran gaji selama tiga hari dari tanggal yang disepakati. Dengan kata lain, apabila perusahaan membayar gaji sebelum empat hari dari tanggal penggajian, maka tidak dianggap sebagai keterlambatan dan tidak dikenai sanksi.

Seperti, pembayaran upah/gaji disepakati pada tanggal 1, maka perusahaan tidak akan dikenakan denda bila pembayaran mundur hingga tanggal 3. Denda akan berlaku apabila upah gaji dibayar pada tanggal 4 atau lebih dari empat hari.

Selain gaji, perusahaan juga memberikan kebijakan THR pada Hari Raya Besar Islam/lebaran idul fitri, THR pada setiap perusahaan tidak selalu sama besarnya. Kebijakan THR ini dimaksudkan untuk meningkat kesejahteraan dan sudut pandang keamanan untuk spesialis. Sesuai dengan Arahan Melayani Tenaga Kerja (Permenaker) Nomor 6 Tahun 2016 tentang Taat THR bagi Dokter Spesialis/Buruh di lingkungan Perusahaan, THR Keagamaan bisa menjadi gaji bukan upah harus dibayarkan oleh pengelola kepada buruh/buruh menjelang kesempatan taat. "Angsuran THR bagi buruh/buruh wajib diberikan setahun sekali oleh perusahaan dan cicilannya sesuai kesepakatan dengan hari-hari lahap khususnya dan dibayarkan tidak setelahnya selama 7 hari beberapa 
waktu terakhir Melahap Agama," kata Buruh Layani M.Hanif Dhakiri dalam Media Gathering di Dinas Tenaga Kerja, Jakarta pada Selasa (6/6).Berdasarkan Permenaker No.6/2016 buruh/buruh yang memiliki masa kerja 1 bulan berhak taat THR dari perusahaan.Spesialis/buruh yang sudah bekerja 12 bulan gigih atau lebih mendapatkan THR untuk santunan sebulan.

Sedangkan pegawai yang telah bekerja paling sedikit 1 bulan gigih namun kurang dari 12 bulan, mengingat THR sebanding dengan jumlah massa pekerjaan yang diisolasi sebesar 12 (dua belas) bulan sekali kompensasi satu bulan. Bagaimanapun, bagi perusahaan yang telah mengatur angsuran THR yang taat dalam pemahaman kerja, Arahan Perusahaan (PP), atau Assentions Kerja Kolaborasi (PKB) dan ternyata jauh lebih baik dan lebih menonjol dibandingkan over arrangements, pada saat itu THR dibayarkan kepada dokter spesialis/buruh harus dilakukan berdasarkan PP atau PKB. Untuk mengontrol cicilan THR dari pengelola kepada Dokter Spesialis/ Spesialis, Dinas Tenaga Kerja membuka Pusat Peduli Lebaran 2017 yang ditemui di Pusat Manfaat Koordinat Satu Pintu (PTSA) Dinas Tenaga Kerja, Gedung B Kantor Kemnaker Jl Gatot Subroto Kav 51 Jakarta Selatan.

"Bukan implikasi bagi Pakar / Buruh untuk mengadukan isu THR, posko tersebut juga bisa menjadi acuan bagi perusahaan untuk mendalami informasi dan nasihat terkait angsuran THR berbasis Permenaker Nomor 6 Tahun 2016," kata Haiyani Rumondang, Ketua.Peningkatan Hubungan Mekanis dan Jaminan Sosial Tenaga Kerja (PHI dan Jamsos) Administrasi Ketenagakerjaan.Sanksi tegas diberikan untuk pelanggaran angsuran THR. Sementara itu, Ketua Pengawas Bidang Kemajuan Tenaga Kerja dan Keamanan dan Kesejahteraan Usaha (PP dan K3) Maruli A.Hasoloan mengatakan, pemerintah berinilasi melakukan pengawasan ketat terhadap pelaksanaan angsuran THR tahun 2017. Hal ini seringkali dalam memahami dengan pengertian dengan Permenaker No 20/2016 tentang Strategi Pemberian Sanksi Spesialis, Arahan Pemerintah (PP) Nomor 78/2015 tentang Stipend di dalamnya mengontrol sanksi tegas bagi perusahaan yang jatuh datar untuk membayar THR.

Visioner perdagangan yang terlambat membayar THR akan dikenakan denda sebesar 5 persen dari seluruh THR yang harus dibayarkan kepada dokter spesialis/buruh untuk kesejahteraan buruh yang maju," kata Maruli. Dalam ekspansi, kata Maruli, pengusaha itu lepas lindungi. Dikenakan sanksi definitif Sanksi yang akan diberikan kepada pengusaha yang ditunjukkan untuk menyalahgunakan sanksi penghitungan dalam bingkai pemberitahuan sanksi yang disusun dan kurungan pada latihan pertukaran. Apalagi, kata Maruli, beban keterbatasan sanksi pada eksekusi pertukaran mempertimbangkan beberapa hal.Secara spesifik, alasan pemogokan tidak diaktualisasikan oleh visioner perdagangan dan mempertimbangkan kondisi anggaran perusahaan seperti yang terlihat dari artikulasi anggaran kuno 2, dan diperiksa oleh pembukuan terbuka."Sanksi untuk membatasi bertukar latihan dipaksakan sampai pelaku usaha menjalankan komitmen membayar THR dengan hormat, menyalahgunakan penyematan sanksi dalam mengatur untuk berhati-hati terhadap sanksi tersusun dan kurungan pada bertukar latihan.

\section{KESIMPULAN}

Menurut As'ad (1995: 93), gaji disebut juga upah, Pekerja akan menerima sejumlah uang yang bisa disebut gaji, sedangkan upah adalah uang yang diterima tidak selalu sama atau tidak pasti dan waktunya telah dijadwalkan. Sudah suatu kewajiban perusahaan untuk memberi kompensasi tiap bulannya, namun perusahaan di subang telat membayar gaji dan THR para buruh yang memicu terjadinya aksi demonstrasi.Namun akhirnya perusahaan menyanggupi untuk membayar kompensasi dan THR dengan metode mencicil. Menurut Notoatmodjo, tujuan dalam kebijakan pemberian sebuah kompensasi/gaji ialah sebagai reward untuk prestasi karyawan, Menjamin keadilan gaji pada karyawan, Untuk mempertahankan karyawan atau mengurangi turnover karyawan, Juga untuk Memperoleh karyawan yang bermutu, Sebagai pengendalian biaya, Selain itu juga untuk memenuhi peraturanperaturan yang berlaku. Dapat dikatakan juga, pemberian kompensasi/gaji juga suatu bentuk apresiasi perusahaan untuk karyawannya atas loyalitas dalam bekerja. Setiap individu memerlukan uang untuk memenuhi kebutuhan sehari-sehari nya, oleh karena itu mereka berkerja keras untuk mendapatkan uang. Untuk menyejahterakan rakyat dalam mendapatkan hak kompensasi dari prusahaan setelah berkerja keras, negara/pemerintah membuat undangundang yang mengatur tentang hukm upah dan gaji.

Saran untuk perusahaan, apabila tidak mampu memenuhi kompensasi para buruh maka sebaiknya perusahaan mengurangi tenaga kerja atau memilih opsi lain yang menguntungkan bagi kedua belah pihak. Lalu untuk peneliti selanjutnya yaitu, sebaiknya mencari lebih banyak sumber agar isi jurnal lebih lengkap pembahasannya. 


\section{DAFTAR PUSTAKA}

ALEMU, D. (2020). EFFECT OF SALARY AND STAFF LOAN ON EMPLOYEES'SAVING DEPOSIT STATUS: CASE STUDY OF OROMIA INTERNATIONAL BANK (Doctoral dissertation, St. Mary>s University).

Cullen, Z., \& Perez-Truglia, R. (2018). How Much Does Your Boss Make?. The Effects of Salary Comparisons,(SSRN Electronic Journal, 2018).

Dewi, Kartika Sari. 2012. Buku Ajar Kesehatan Mental. Semarang: CV. Lestari Mediakreatif

Ertanto, Y. D., \& SUHARNOMO, S. (2011). Pengaruh gaji terhadap kinerja karyawan dengan self esteem sebagai variabel intervening (studi pada PDAM Kabupaten Grobogan) (Doctoral dissertation, Universitas Diponegoro).

Indriyani, A. (2014). Analisis pengaruh gaji dan tunjangan kesejahteraan terhadap produktivitas kerja karyawan operation department pt. export leaf indonesia. Jurnal Paradigma Universitas Islam Batik Surakarta, 12(01), 115589.

Kalangi, R. (2015). PENGEMBANGAN SUMBER DAYA MANUSIA DAN KINERJA APARAT SIPIL NEGARA DI KABUPATEN KEPULAUAN SANGIHE PROVINSI SULAWESI UTARA. Jurnal LPPMBidang EkoSosBudKum, Vol 2.

Kalangi, R. (2015). PENGEMBANGAN SUMBER DAYA MANUSIA DAN KINERJA APARAT SIPIL NEGARA DI KABUPATEN KEPULAUAN SANGIHE PROVINSI SULAWESI UTARA. Jurnal LPPMBidang EkoSosBudKum, Vol 2.

Kasema, J. K. (2018). HUBUNGAN ANTARA PSYCHOLOGICAL WELL BEING DAN KEPUASAN KERJA PADA KARYAWAN DI KANTOR X. Jurnal Maneksi, 7 no 1.

Logo, J. F. B., Wantoro, A., \& Susanto, E. R. (2020).Model Berbasis Fuzzy Dengan Fis Tsukamoto Untuk Penentuan Besaran Gaji Karyawan Pada Perusahaan Swasta. Jurnal Teknoinfo, 14(2), 124-130.

Pragiwani, M., Ammar, M., \& Alexandri, M. B. (2020). BIAYA GAJI, BIAYA PELATIHAN TENAGA KERJA, JUMLAH KARYAWAN DAN PRODUKTIVITAS KARYAWAN (STUDI KASUS PADA PERUSAHAAN PERKEBUNAN DI BEI TAHUN 2013-2018). Responsive: Jurnal Pemikiran Dan Penelitian Administrasi, Sosial, Humaniora Dan Kebijakan Publik, 3(2), 69-75.

Prihantoro, A. (2012). PENINGKATAN KINERJA SUMBER DAYA MANUSIA MELALUI MOTIVASI, DISIPLIN, LINGKUNGAN KERJA, DAN KOMITMEN. Vol.8.

Prihantoro, A. (2012). PENINGKATAN KINERJA SUMBER DAYA MANUSIA MELALUI MOTIVASI, DISIPLIN, LINGKUNGAN KERJA, DAN KOMITMEN. Vol.8.

Sari, I. (2020). ANALISIS PERHITUNGAN DAN PELAPORAN PPH PASAL 21 ATAS TUNJANGAN HARI RAYA (THR) KARYAWAN TETAP PADA CV. CIPTA CITRA PRATISARA PALEMBANG (Doctoral dissertation, Universitas Muhammadiyah Palembang).

Sutanto, E. M., \& Patty, F. M. (2014). PERSEPSI AKAN GAJI, MOTIVASI KERJA, DAN KINERJA KARYAWAN PT AMITA BARA SEJAHTERA. Journal of Bussiness and Banking, 4 No 1, 1-14.

Sutanto, E. M., \& Patty, F. M. (2014). PERSEPSI AKAN GAJI, MOTIVASI KERJA, DAN KINERJAKARYAWAN PT AMITA BARA SEJAHTERA. Journal of Bussiness and Banking, 4 No 1, 1-14.

Widyani, A. A. D. (2019). Ebook-Etika Bisnis Perspektif Teori dan Praktis. KARTI

Zuana, K. R., \& Sidharta, I. (2014). SISTEM INFORMASI PEMOTONGAN PPH 21 DIATAS GAJI KARYAWAN PT RAJAWALI TEHNIK. Jurnal Computech \& Bisnis, 8 No 2, 112-121.

Zuana, K. R., \& Sidharta, I. (2014). SISTEM INFORMASI PEMOTONGAN PPH 21 DIATAS GAJI KARYAWAN PT RAJAWALI TEHNIK. Jurnal Computech \& Bisnis, 8 No 2, 112-121. 